\title{
PENGARUH PENERAPAN STRATEGI CUSTOMER RELATIONSHIP MARKETING TERHADAP KEPUASAN NASABAH PADA PT. PRO CAR INTERNATIONAL FINANCE CABANG PADANG
}

\author{
Hari Mulyadi, Febsri Susanti \\ Sekolah Tinggi Ilmu Ekonomi KBP \\ febsrisusanti@akbpstie.ac.id
}

\begin{abstract}
ABSTRAK
Penelitian ini bertujuan untuk mengetahui apakah penerapan strategi customer relationship marketing (tangible, empathy, reliability, responsiveness, assurance) berpengaruh terhadap kepuasan nasabah pada PT. Procar International Finance cabang Padang. Dalam penelitian ini, Sampel yang diambil sebanyak 100 responden menggunakan teknik conveniencesampling. Teknik analisis data yang digunakan adalah observasi, kuesioner dan dokumentasi. Hasil penelitian berdasarkan hasil uji regresi linear berganda variabel Tangible $\left(\mathrm{X}_{1}\right)$ berpengaruh positif dan signifikan terhadap Kepuasan Nasabah (Y) diketahui bahwa nilai koefisien tangible bernilai positif 0.173 , variabel Empathy $\left(\mathrm{X}_{2}\right)$ berpengaruh positif dan signifikan terhadap Kepuasan Nasabah (Y) diketahui bahwa nilai koefisien empathy bernilai positif 0.377 , variabel Reliability $\left(\mathrm{X}_{3}\right)$ berpengaruh positif dan signifikan terhadap Kepuasan Nasabah (Y) diketahui bahwa nilai koefisien reliability bernilai positif 0.462 , variabel Responsiveness ( $\left.\mathrm{X}_{4}\right)$ berpengaruh positif dan signifikan terhadap Kepuasan Nasabah (Y) diketahui bahwa nilai koefisien responsiveness bernilai positif 0.199, variabel Assurance $\left(\mathrm{X}_{5}\right)$ berpengaruh positif dan signifikan terhadap Kepuasan Nasabah (Y) diketahui bahwa nilai koefisien assurance bernilai positif 0.684 , maka dapat dikatakan bahwa variable tangible, empathy, reliability, responsiveness dan assurance secara bersama-sama atau simultan berpengaruh signifikan terhadap variable kepuasan nasabah (Y).
\end{abstract}

Kata Kunci: Tangible, Empathy, Reliability, Responsiveness, Assurance, Kepuasan Nasabah. 


\section{Pendahuluan}

Saat ini relationship menjadi topik utama dalam aktivitas bisnis, Kebanyakan perusahaan, secara financial, bertujuan ingin mendapatkan profit yang maksimal dari hasil operasinya dengan memaksimalkan nilai sahamnya. Disisi lain dalam pemasaran, kepuasaan nasabah merupakan tujuan dari setiap perusahaan. Peningkatan kualitas atas produk serta layanan yang superior kepada pasar (konsumen) merupakan usaha untuk mewujudkan kepuasan nasabah terhadap produk dan layanan yang diberikan. Usaha tersebut tidak terlepas dari adanya perubahan yang terjadi terhadap lingkungan bisnis, persaingan yang semakin ketat, kemajuan teknologi serta perubahan dalam kebutuhan dan keinginan pasar, yang menuntut para pemasar untuk mengubah strategi dan taktiknya dari productoriented menjadi market-oriented.

$$
\text { Winer (2001, p. 12) }
$$
mendefenisikan customer relationship marketing sebagai strategi untuk membangun hubungan yang baik dengan pelanggan dalam jangka panjang dengan mengkombinasikan kemampuan untuk merespon secara langsung dan untuk melayani pelanggan dengan interaksi yang tinggi, Untuk mendukung penerapan strategi cutomer relationship marketing, diperlukan suatu perangkat berupa pendekatan manajemen, yaitu customer relationship management (CRM).
Menurut Sunarto (2003: 146) para pelanggan yang tidak puas bereaksi sebaliknya, mereka mungkin membuang atau mengembalikan produk tersebut, mereka mungkin mencari infromasi yang mengkonfirmasikan nilai produk yang tinggi tersebut. Mereka mungkin mengambil tindakan publik seperti mengajukan keluhan ke perusahaan, pergi ke pengacara, atau mengadu ke kelompok-kelompok lain (seperti lembaga-lembaga bisnis, swasta atau pemerintah) tindakan pribadi dapat berupa memutuskan untuk berhenti membeli produk tersebut (pilihan untuk keluar) atau memperingatkan teman-teman (pilihan untuk bicara), dalam semua kejadian tersebut penjual telah gagal memuaskan pelanggannya.

Sebaliknya, apabila perusahaan mampu mempertahankan kepuasan konsumen, kepuasan tersebut akan menunjukan kemungkinan yang lebih tinggi untuk membeli kembali produk tersebut (Sunarto, 2003). Mereka juga akan merekomendasikan perusahaan pada orang-orang yang dikenalnya, kegiatan word-of-mouth sangat membantu perusahaan dalam kegiatan promosi. Karena promosi word-of-mouth lebih baik dibanding dengan promosi yang pernah ada seperti iklan dalam media cetak maupun elektronik (Kotler, 2000).

Salah satu contoh perusahaan jasa adalah perusahaan pembiayaan, selain dari tolak ukur kualitas jasa yang ditawarkan masih tidak jelas, ketatnya persaingan pada perusahaan 
pembiayaan di Indonesia, membuat sebagian perusahaan tersebut menggunakan konsep strategi CRM ini, PT. Pro Car International Finance adalah salah satunya.

PT. Pro Car International Finance (PIF) telah mengadaptasi strategi CRM, terlihat dari adanya memberikan layanan kepada masyarakat luas melalui kredit investasi, modal kerja dan multi guna dengan kemudahan yang senantiasa ditingkatkan antara lain, pengolahan data on line diseluruh cabang, pembayaran kewajiban nasabah dapat dilayani diseluruh cabang serta dapat melalui Kantor Pos dan ATM Prima dan sebagai komitmen pelayanan prima kepada nasabah, PT. Pro Car International Finance membuka pusat pengaduan nasabah (Call Center).

Semua produk yang ditawarkan pada nasabah, proses penawarannya sampai cara bertransaksi disesuaikan dengan keinginan nasabah, PT. Pro Car International Finance juga berusaha melakukan komunikasi interaktif dengan masing-masing nasabahnya. Komunikasi yang dilakukan bukan hanya komunikasi satu arah dan berbentuk mass comunication, tetapi komunikasi dua arah secara individual. Pelanggan sangat diharapkan memberikan komentar terhadap layanan secara langsung (melalui front-liner) untuk perbaikan kearah yang sempurna. Hal ini semata-mata untuk kepuasan nasabah mereka.

\subsection{Rumusan Masalah}

Berdasarkan latar belakang yang diuraikan diatas maka dapat dirumuskan masalah sebagai berikut

1. Bagaimana pengaruh tangible terhadap kepuasan nasabah pada PT. Pro Car International Finance Cabang Padang?

2. Bagaimana pengaruh empathy terhadap kepuasan nasabah pada PT. Pro Car International Finance Cabang Padang?

3. Bagaimana pengaruh reliability terhadap kepuasan nasabah pada PT. Pro Car International Finance Cabang Padang?

4. Bagaimana pengaruh responsiveness terhadap kepuasan nasabah pada PT. Pro Car International Finance Cabang Padang?

5. Bagaimana pengaruh assurance terhadap kepuasan nasabah pada PT. Pro Car International Finance Cabang Padang?

\section{Landasan Teori}

\section{Pengertian Customer Relationship} Marketing

Pengertian lain dari

Customer Relationship Marketing adalah suatu proses untuk menciptakan, mempertahankan dan meningkatkan hubungan-hubungan yang kuat dengan para nasabah dan stakeholder lainnya. Selain merancang strategi baru untuk menarik nasabah baru dan menciptakan transaksi dengan mereka, perusahaan terus menerus sedang berjuang mati-matian untuk mempertahankan nasabah yang ada 
dan membangun relasi jangka panjang yang mampu mendatangkan laba dengan mereka. (Kotler dan Amstrong, 2004:789).

$$
\text { Menurut Chan, Syafrudin }
$$
(2003) dimensi dari Strategi Customer Relationship Marketing adalah sebagai berikut :

a) Variable Tangible atau bukti fisik $\left(\mathrm{X}_{1}\right)$

Merupakan derajat penampilan sarana fisik, peralatan, front desk yang ada pada perusahaan. Dalam hal ini mencakup, desain dan tata letak, kenyamanan ruangan, kebersihan ruangan ,dekorasi ruangan ,tempat parkir yang luas dan aman.

b) Variable Emphaty atau empati $\left(\mathrm{X}_{2}\right)$

Merupakan derajat kesungguhan pelayanan yang diberikan perusahaan terhadap nasabah. Dalam hal ini penilaian mencakup perhatian yang diberikan karyawan perusahaan pada setiap nasabah, meliputi kemudahan dalam melakukan keramahan dan kesopanan karyawan, komunikasi yang baik dan memahami kebutuhan nasabah.

c) Variable Reliability atau kehandalan $\left(\mathrm{X}_{3}\right)$

Merupakan derajat kemampuan untuk memberikan pelayanan yang dijanjikan dengan baik oleh perusahaan. Keandalan dapat diartikan mengerjakan dengan benar sampai kurun waktu tertentu. Pemenuhan janji pelayanan yang tepat dan memuaskan meliputi kecepatan dan ketelitian pelayanan.

d) Variable Responsiveness atau responsif $\left(\mathrm{X}_{4}\right)$

Merupakan derajat kemampuan perusahaan dalam pemberian tanggapan terhadap permintaan pelayanan nasabah. Dalam hal ini mencakup ketepatan waktu dan kecakapan dalam menanggapi keluhan pelanggan (prosedur resolusi masalah).

e) Variable Assurance atau jaminan $\left(\mathrm{X}_{5}\right)$

Merupakan derajat tingkat keahlian dan pengetahuan yang dibutuhkan untuk dapat memberikan pelayanan dan kepuasan dengan tepat dan sopan santun, rasa hormat dimana nasabah merasa aman terhadap pelayanan yang diberikan pihak perusahaan. Dalam hal ini penilaian mencakup keyakinan nasabah terhadap pengetahuan dan kemampuan karyawan dalam memberikan keterampilan dan jaminan keamanan pelayanan yang diberikan.

\section{Pengertian Kepuasan Nasabah}

Menurut Oliver yang dikutip oleh Barnes (2003 : 64) kepuasan nasabah adalah tanggapan nasabah atas terpenuhinya kebutuhannya. Hal ini berarti penilaian bahwa suatu bentuk keistimewaan dari suatu barang dan jasa, memberikan tingkat kenyamanan yang terkait dengan pemenuhan suatu kebutuhan, termasuk pemenuhan kebutuhan di bawah harapan atau pemenuhan 
kebutuhan melebihi harapan nasabah. Nasabah adalah orangorang yang dimana keputusannya memperngaruhi kekayaan perusahaan. Mereka mungkin suatu kelompok yang kompleks dan terdiri dari berbagai lapisan, tapi kita harus mengetahui dan melayani mereka semua untuk menjamin kesejahteraan perusahaan.

Selanjutnya Tjiptono (2009 : 146) memberikan definisi kepuasan nasabah merupakan evaluasi purnabeli di mana alternatif yang dipilih sekurang-kurangnya memberikan hasil (outcome) sama atau melampaui harapan nasabah.

Pada umumnya kepuasan nasabah mencakup 5 indikator utama (Tjiptono, 2009) yaitu :

1. Kualitas Produk

Kualitas produk merupakan suatu jaminan dalam rangka memenuhi kebutuhan nasabah dalam memilih suatu produk dan dalam masalah ini citra rasa pribadi sangatlah berperan.

2. Kualitas Pelayanan

Kualitas pelayanan merupakan upaya pemenuhan kebutuhan yang dibarengi dengan keinginan nasabah serta ketepatan cara penyampaiannya agar dapat memenuhi harapan dan kepuasan nasabah tersebut.

3. Emosional

Emosional merupakan respon emosional dari nasabah setelah melalui rangkaian evaluasi yang bersifat rasional dan emosional saat mempertimbangkan manfaat dari suatu produk.
4. Harga

Harga merupakan sejumlah uang yang dibebankan atas suatu produk atau jasa, atau jumlah nilai tukar nasabah untuk manfaat-manfaat yang diterima karena produk atau jasa tersebut.

5. Biaya

Biaya merupakan biaya yang dikeluarkan perusahaan untuk mempertahankan kualitas.

\section{Hubungan Antara Customer Relationship Marketing dengan Kepuasan Nasabah}

Menurut Yasin (2001:75), mengungkapkan bahwa customer relationship akan sangat efektif pada nasabah yang tepat, yaitu nasabah yang sangat memperhatikan dan mengharapkan pelayanan yang konsisten dan tepat waktu. Dari pendapat tersebut, dapat dilihat bahwa dalam menjalankan strategi relationship marketing, perusahaan juga harus memperhatikan mengenai kualitas pelayanan. Karena dengan memberikan pelayanan yang maksimal kepada nasabah, dalam hal ini pihak-pihak yang langsung berhubungan dan berinteraksi dengan nasabah seperti operator, resepsionis, teller, ataupun customer service, maka akan terjalinan hubungan yang erat antara perusahaan dan nasabah. Sedangkan menurut Chan (2003:6), customer relatonship adalah pelayanan secara lebih dekat dengan menciptakan komunikasi dua arah sehingga membentuk suatu hubungan yang saling menguntungkan antara nasabah dan perusahaan. Melalui customer 
relationship, perusahaan dapat memberikan nilai lebih pada nasabah, menciptakan kepuasan nasabah dengan memahami keinginan serta kebutuhan mereka, dan mengadakan usaha-usaha untuk lebih mengenal nasabah dengan baik. Dengan memberikan pelayanan yang maksimal kepada nasabah, dalam hal ini pihak-pihak yang langsung berhubungan dan berinteraksi dengan nasabah akan tercipta jalinan hubungan yang erat antara perusahaan dan nasabah.

\section{Meode Penelitian}

Jenis penelitian yang digunakan adalah penelitian survei yang bersifat kuantitatif dan umumnya menggunakan kuesioner sebagai alat pengumpulan datanya. Penelitian ini dilakukan di PT. Pro Car International Finance Cabang Padang jumlah responden yang diteliti sebanyak 100 responden.

Teknik dan Pengumpulan Data yang digunakan dengan menyebarkan kuesioner, setelah disebarkan lalu diuji per item pernyataan menggunakan uji validitas dan uji reliabilitas serta menggunakan analisis deskriptif untuk menghitung skala TCR. Selanjutnya Uji Asumsi Klasik terdapat Uji Normalitas dan Uji Multikolinearitas dan menggunakan analisis regresi berganda. $\mathrm{Uji}$ Hipotesis dilakukan dengan Uji $\mathrm{T}$ dan Uji $F$ serta Koefisien Determinasi (R).

\section{Hasil Penelitian dan Pembahasan. Pengaruh Tangible $\left(\mathrm{X}_{1}\right)$ terhadap kepuasan nasabah $(\mathbf{Y})$}

Dalam penelitian ini adalah variable tangible berpengaruh positif dan signifikansi terhadap kepuasan nasabah. Dengan signifikansi 0,006 $<0,05$. Hal ini berarti tangible berpengaruh positif dan signifikansi terhadap kepuasan nasabah. Sehingga dapat dikatakan bahwa Ho ditolak dan Ha diterima. Sedangkan untuk distribusi frekuensi tangible didapat hasil dari skala TCR rata-rata sebesar 78.53 dalam kategori cukup baik.

Berdasarkan hasil uji ANOVA atau F test pada tabel 4.27 didapatkan $\mathrm{F}$ hitung sebesar 32.756 dengan tingkat signifikansi 0,000 . Karena tingkat signifikansi $0,000<$ 0,05 maka model regresi dapat digunakan untuk memprediksi kepuasan nasabah (Y) atau dikatakan bahwa variabel tangible $\left(\mathrm{X}_{1}\right)$ secara bersama-sama atau simultan berpengaruh signifikan terhadap variabel kepuasan nasabah (Y).

Menurut kamus umum bahasa Indonesia, karya WJS Poerwadarminta

(1985) tangible merupakan adanya penampakan berupa fasilitas-fasilitas penunjang, petugas ataupun sarana komunikasi yang menyertai produk tersebut. Dengan adanya tangible seperti fasilitas, karyawan dan material komunikasi dan peralatan maka akan muncul suatu kepuasan pada nasabah.

Penelitian Rahayu Triastiity SL, Triyaningsih, (2012) tentang 
Pengaruh Tangible, Reliability, Responsiveness, Assurance dan Empathy Terhadap Kepuasan Konsumen Mahasiswa Fakultas Ekonomi Universitas Slamet Riyadi Surakarta, dimana hasil penelitian pengaruh tangible terhadap kepuasan konsumen diperoleh kesimpulan ada pengaruh posisitf dan signigfikan tangible terhadap kepuasan konsumen.

Penelitian Mira Safitri, (2009) tentang Pengaruh Penerapan Strategi Customer Relationship Marketing Terhadap Kepuasan Pelanggan Pada Eighteen Boutique Plaza Andalas Padang Mahasiswa STIE"KBP'PADANG, dimana hasil penelitian terhadap pengaruh tangible menggambarkan bahwa tidak satupun butir pertanyaan yang mendekati nilai koefisien berdasarkan standar penelitian. Artinya tangible belum mencapai tingkat kepuasan yang memadai seperti yang diharapkan. Dari beberapa penelitian diatas maka dapat ditarik hipotesis :

$\mathrm{H}_{1}$ = Diduga tangible berpengaruh positif dan signifikan terhadap kepuasan nasabah.

\section{Pengaruh Empathy $\left(\mathrm{X}_{2}\right)$ terhadap kepuasan nasabah (Y)}

Dalam penelitian ini adalah variable empathy berpengaruh positif dan signifikansi terhadap kepuasan nasabah. Dengan signifikansi 0,002 $<0,05$ Hal ini berarti empathy berpengaruh terhadap kepuasan nasabah. Sehingga dapat dikatakan bahwa Ho ditolak dan Ha diterima.
Sedangkan untuk distribusi frekuensi empathy didapat hasil dari skala TCR rata-rata sebesar 82.4 dalam kategori baik.

Menurut kamus umum bahasa Indonesia, karya WJS Poerwadarminta

(1985) empathy merupakan adanya perhatian secara individual dari perusahaan terhadap nasabahnya. Dengan adanya empathy seperti mau mendengar, mau menghubungi, dan memahami kebutuhan serta keinginan nasabah maka akan muncul suatu kepuasan tersendiri bagi nasabah.

Penelitian Rahayu Triastiity SL, Triyaningsih, (2012) tentang Pengaruh Tangible, Reliability, Responsiveness, Assurance dan Empathy Terhadap Kepuasan Konsumen Mahasiswa Fakultas Ekonomi Universitas Slamet Riyadi Surakarta, dimana hasil penelitian pengaruh empathy terhadap kepuasan konsumen diperoleh kesimpulan ada pengaruh posisitf dan signifikan empathy terhadap kepuasan konsumen.

Penelitian Mira Safitri, (2009) tentang Pengaruh Penerapan Strategi Customer Relationship Marketing Terhadap Kepuasan Pelanggan Pada Eighteen Boutique Plaza Andalas Padang Mahasiswa STIE"KBP'PADANG, dimana hasil penelitian terhadap pengaruh empathy memperlihatkan bahwa pelanggan merasakan kepuasan dalam melakukan transaksi yang memiliki koefisien yang lebih besar dari koefisien standar. Dari beberapa 
penelitian diatas maka dapat ditarik hipotesis :

$\mathrm{H}_{2}=$ Diduga empathy berpengaruh positif dan signifikan terhadap kepuasan nasabah.

\section{Pengaruh Reliability $\left(\mathrm{X}_{3}\right)$ terhadap kepuasan nasabah (Y)}

Dalam penelitian ini adalah variable reliability berpengaruh positif dan signifikansi terhadap kepuasan nasabah. Dengan signifikansi $0,255>0,05$ Hal ini berarti reliability tidak berpengaruh terhadap kepuasan nasabah. Sehingga dapat dikatakan bahwa Ho diterima dan Ha ditolak. Sedangkan untuk distribusi frekuensi reliability didapat hasil dari skala TCR rata-rata sebesar 79.1 dalam kategori cukup baik.

Menurut kamus umum
bahasa Indonesia, karya WJS
(1985) reliability merupakan kemampuan perusahaan untuk memberikan pelayanan sesuai yang dijanjikan dan seberapa jauh suatu perusahaan mampu memberikan pelayanan yang akurat.

Penelitian Rahayu Triastiity SL, Triyaningsih, (2012) tentang Pengaruh Tangible, Reliability, Responsiveness, Assurance dan Empathy Terhadap Kepuasan Konsumen Mahasiswa Fakultas Ekonomi Universitas Slamet Riyadi Surakarta, dimana hasil penelitian pengaruh reliability terhadap kepuasan konsumen diperoleh kesimpulan ada pengaruh positif dan signifikan reliability terhadap kepuasan konsumen.

Penelitian Mira Safitri, (2009) tentang Pengaruh Penerapan Strategi Customer Relationship Marketing Terhadap Kepuasan Pelanggan Pada Eighteen Boutique Plaza Andalas Padang Mahasiswa STIE"KBP"PADANG, dimana hasil penelitian terhadap pengaruh reliability memiliki pengaruh yang signifikan terhadap kepuasan pelanggan. Dari beberapa penelitian diatas maka dapat ditarik hipotesis : $\mathrm{H}_{3}=$ Diduga reliability berpengaruh positif dan signifikan terhadap kepuasan nasabah.

\section{Pengaruh Responsiveness $\left(\mathbf{X}_{4}\right)$ terhadap kepuasan nasabah $(Y)$}

Dalam penelitian ini adalah variable responsiveness berpengaruh positif dan signifikansi terhadap kepuasan nasabah. Dengan signifikansi $0,085>0,05$ Hal ini berarti responsiveness tidak berpengaruh terhadap kepuasan nasabah. Sehingga dapat dikatakan bahwa Ho diterima dan Ha ditolak. Sedangkan untuk distribusi frekuensi responsiveness didapat hasil dari skala TCR rata-rata sebesar 76.26 dalam kategori cukup baik.

Menurut kamus umum bahasa Indonesia, karya WJS Poerwadarminta

(1985) responsiveness merupakan adanya keinginan untuk menolong konsumen dari menyediakan kecepatan dan ketepatan pelayanan.

Penelitian Rahayu Triastiity SL, Triyaningsih, (2012) tentang 
Pengaruh Tangible, Reliability, Responsiveness, Assurance dan Empathy Terhadap Kepuasan Konsumen Mahasiswa Fakultas Ekonomi Universitas Slamet Riyadi Surakarta, dimana hasil penelitian pengaruh responsiveness terhadap kepuasan konsumen diperoleh kesimpulan ada pengaruh positif dan signifikan reliability terhadap kepuasan konsumen.

Penelitian Mira Safitri, (2009) tentang Pengaruh Penerapan Strategi Customer Relationship Marketing Terhadap Kepuasan Pelanggan Pada Eighteen Boutique Plaza Andalas Padang Mahasiswa STIE"KBP"PADANG, dimana hasil penelitian terhadap pengaruh reliability memiliki pengaruh yang signifikan terhadap kepuasan pelanggan. Dari beberapa penelitian diatas maka dapat ditarik hipotesis :

$\mathrm{H}_{4}=$ Diduga responsiveness berpengaruh positif dan signifikan terhadap kepuasan nasabah.

\section{Pengaruh Assurance $\left(\mathrm{X}_{5}\right)$ terhadap kepuasan nasabah (Y)}

Dalam penelitian ini adalah variable assurance berpengaruh positif dan signifikansi terhadap kepuasan nasabah. Dengan signifikansi $0,000<0,05$ Hal ini berarti assurance berpengaruh terhadap kepuasan nasabah. Sehingga dapat dikatakan bahwa Ho ditolak dan Ha diterima. Sedangkan untuk distribusi frekuensi assurance didapat hasil dari skala TCR rata-rata sebesar 83.10 dalam kategori baik.
Menurut kamus umum
bahasa Indonesia, karya WJS
Poerwadarminta
(1985) assurance merupakan adanya
pengetahuan dari karyawan dalam
menanamkan kepercayaan atas
produk tersebut.
Penelitian Rahayu Triastiity SL, Triyaningsih, (2012) tentang Pengaruh Tangible, Reliability, Responsiveness, Assurance dan Empathy Terhadap Kepuasan Konsumen Mahasiswa Fakultas Ekonomi Universitas Slamet Riyadi Surakarta, dimana hasil penelitian pengaruh assurance terhadap kepuasan konsumen diperoleh kesimpulan ada pengaruh positif dan signifikan assurance terhadap kepuasan konsumen.

Penelitian Mira Safitri, (2009) tentang Pengaruh Penerapan Strategi Customer Relationship Marketing Terhadap Kepuasan Pelanggan Pada Eighteen Boutique Plaza Andalas Padang Mahasiswa STIE"KBP"PADANG, dimana hasil penelitian terhadap pengaruh assurance memiliki pengaruh yang signifikan terhadap kepuasan pelanggan. Dari beberapa penelitian diatas maka dapat ditarik hipotesis : $\mathrm{H}_{5}=$ Diduga assurance berpengaruh positif dan signifikan terhadap kepuasan nasabah.

\section{Kesimpulan}

Berdasarkan hasil pengujian hipotesis maka dapat ditarik inti kesimpulan dari permasalahan yang dibahas dalam penelitian ini yaitu: 
1. Terdapat pengaruh positif dan signifikan antara tangible $\left(\mathrm{X}_{1}\right)$ terhadap kepuasan nasabah sebesar 0.173 dan didapat hasil skala TCR rata-rata sebesar 78.52 dengan kategori cukup baik.

2. Terdapat pengaruh positif dan signifikan antara empathy $\left(\mathrm{X}_{2}\right)$ terhadap kepuasan nasabah sebesar 0.377 dan didapat hasil skala TCR rata-rata sebesar 82.4 dengan kategori baik.

3. Terdapat pengaruh positif dan signifikan antara reliability $\left(\mathrm{X}_{3}\right)$ terhadap kepuasan nasabah sebesar 0.462 dan didapat hasil skala TCR rata-rata sebesar 79.1 dengan kategori cukup baik.

4. Terdapat pengaruh positif dan signifikan antara responsiveness $\left(\mathrm{X}_{4}\right)$ terhadap kepuasan nasabah sebesar 0.199 dan didapat hasil skala TCR rata-rata sebesar 76.26 dengan kategori cukup baik.

5. Terdapat pengaruh positif dan signifikan antara assurance $\left(\mathrm{X}_{5}\right)$ terhadap kepuasan nasabah sebesar 0.684 dan didapat hasil skala TCR rata-rata sebesar 83.10 dengan kategori baik.

\section{DAFTAR PUSTAKA}

Abdurahman, Maman. 2011. Dasardasar Metode Statistika Untuk Penelitian. Bandung : CV Pustaka Setia.

A, Syawir dan Erina I. 2007. Pengaruh Relationship Marketing Terhadap
Customer Value Pada Tosca

Salon \& Spa di Supermall

Pakuwon Indah Surabaya.

Jurnal Manajemen

Pemasaran, Vol.1, hal 52-64.

Barnes, James G., 2003. Secrets Of Customer Relationship

Management, Penerbit:

Andi, Yogyakarta.

Bungin, Burhan. 2005. Metodologi Penelitian Kuantitatif. Jakarta: PT Rineka Cipta.

Chan, Syafrudin. 2003. Relationship Marketing. Jakarta: Gramedia Pustaka Utama.

Denny Bagus. 2009. Penerapan Customer Relationship Marketing (CRM) sebagai Stratregi Bersaing :http://jurnalsdm.blogspot.co.id/2009/08/p enerapan-customerrelationship.html?m=1

Djojo, Adji. 2012. .Aplikasi Praktis SPSS Dalam Penelitian. Batam : Gava Media.

Gautama, Idris. 2005. Relationship Marketing dan Pemanfaatan Teknologi Informasi dalam Customer Relationship Management Untuk Memenangkan Persaingan Bisnis. Seminar Nasional Aplikasi Teknologi Informasi 2005 (SNATI 2005). 
Ghozali, Imam. 2001. Aplikasi Analisis Multivariate Dengan Program SPSS. Semarang : Badan Penerbit Universitas Diponegoro.

Idris. (2010). Aplikasi Model Analisis Data Kuantitatif dengan Program SPSS. Padang: FE UNP.

Irawan, Handi. 2004. 10 Prinsip Kepuasan Pelanggan, cetakan kelima, Penerbit : Elex Media Komputindo, Jakarta.

Irianto, Agus. (2010). Statistik Konsep Dasar dan Aplikasi dan pengembanganya. Jakarta : Kencana.

Kotler, Philip., dkk. Manajemen Pemasaran Perspektif Asia. Penerbit Andi Bekerjasama dengan Pearson Education Asia Pte. Ltd. 2000.

Kotler, Philip dan Gary Amstrong. 2004. Dasar-Dasar Pemasaran, Edisi ke-9, alih bahasa:Alexander Sindoro. Jakarta: PT. Indeks.

Kotler, Philip. Manajemen Pemasaran. Terjemahan Hendra Teguh, Ronny A. Rusli dan Benyamin Molan. Jilid II Edisi Milenium. Penerbit PT Indeks. Jakarta. 2002.
Marlius, D. (2016). Pengaruh Bauran Pemasaran Jasa Terhadap Minat Nasabah Dalam Menabung Pada Bank Nagari Cabang Muaralabuh. https://doi.org/10.31227/osf.i o/vdqgx

Marlius, D. (2018). Loyalitas Nasabah Bank Nagari Syariah Cabang Bukittinggi Dilihat Dari Kualitas Pelayanan. Jurnal Pundi. Volume 1. No. 3. Hal.12-22. https://doi.org/10.31575/jp.v1 i3.60

Marlius, D. (2018). Pengaruh Dimensi Kualitas Pelayanan Website Akademik Terhadap Kepuasan Mahasiswa Pada STIE "KBP". Jurnal Ipteks Terapan. Volume 12. No. 2. Hal. 116-128. http://doi.org/10.22216/jit.20 18.v12i2.633

Santoso, Purbayu Budi dan Ashari. 2005. Analsis Statistik dengan Microsoft Excel \& SPSS. Andi, Yogyakarta.

Sunarto SE., MM. Manajemen Pemasaran. BPFE-UTS, Jogjakarta. 2003

Susanti, F. (2015). Pengaruh Bauran Promosi Terhadap Keputusan Klien Dalam Memilih Radio Carano Sebagai Media Promosi Iklan. https://doi.org/10.31227/osf.i o/b9ws7 
Tjiptono, Fandy. 2009. Manajemen

Jasa, edisi kedua, cetakan

kedua, Andi,Yogyakarta. 